\title{
The effect of cooling rate on immiscible silicate liquid microstructure: an example from the Palaeogene dykes of Northeast England
}

\author{
Victoria C. Honour ${ }^{1}$, Marian B. Holness ${ }^{1}$, Michael J. Stock ${ }^{1,2}$ \\ ${ }^{1}$ Department of Earth Sciences, University of Cambridge, England, UK \\ ${ }^{2}$ Department of Geology, Trinity College Dublin, Dublin, Ireland \\ email:vch28@cam.ac.uk \\ email: marian@esc.cam.ac.uk \\ email: stockm@cam.ac.uk
}

\section{ABSTRACT}

The migration and accumulation of immiscible silicate liquids may play a significant role in the differentiation of crustal magma bodies and the formation of some economic mineral deposits. However, our understanding of the processes that control the segregation of these liquids is currently limited by the short timescales of petrological experiments. Detailed microstructural investigations of Paleogene basaltic dykes from Northeast England, coupled with simple 1D thermal models, constrain the effects of cooling rate on the microstructure of unmixed immiscible silicate liquids under natural conditions. The size of unmixed Fe-rich droplets within a continuous silicic phase is related to the cooling rate by a power law, with droplet diameter increasing with decreasing cooling rate, accompanied by an increase in the number of droplets. Fe-rich droplet coarsening is a result of diffusion-controlled growth. The average apparent aspect ratio and grain size of matrix plagioclase crystals indicate that

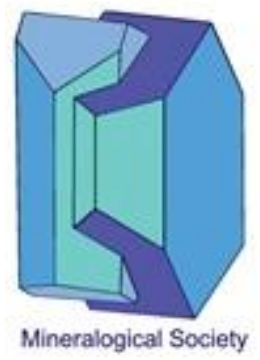

This is a 'preproof' accepted article for Mineralogical Magazine. This version may be subject to change during the production process.

DOI: 10.1180/mgm.2019.71 
nucleation and growth of these grains likely occurred in a static (or only weakly convecting) fluid dynamical regime.

\section{KEYWORDS}

Immiscibility, Mull dyke swarm, Cooling rate, Aspect ratio, In situ crystallisation.

\section{INTRODUCTION}

As mafic silicate melts cool and crystallise under certain pressure, temperature, compositional, and oxygen fugacity conditions, they can unmix to form an emulsion of two immiscible liquids: one rich in $\mathrm{Si}$ and the other dominated by $\mathrm{Fe}$ (e.g. Charlier and Grove, 2012). Existing work on the evolution of silicate liquid immiscibility in crystal mush and bulk magmas has typically focused on the chemistry of the unmixed liquids (e.g. Roedder, 1951; Veksler et al., 2007; Charlier and Grove, 2012). However, limited textural observations suggest that cooling rate may have a major effect on the distribution and coarsening of an emulsion (Martin and Kushiro, 1991). As the migration and accumulation of these unmixed liquids are potentially linked to the differentiation of crustal magma bodies (e.g. Veksler et al., 2007) and the formation of some economic mineral deposits (e.g. magnetite-hematiteapatite ores; Frietsch (1978)), further work is essential to establish the controls on their microstructural evolution.

Previous studies investigating the microstructures of systems containing immiscible silicate liquids have typically focussed on centimetre-sized experimental charges (e.g. Veksler et al., 2006; Veksler et al., 2008; Charlier and Grove, 2012) or kilometre-scale igneous intrusions (Holness et al., 2011), each with very different thermal histories. Experimental investigations are limited to cooling rates of $\gtrsim 1^{\circ} \mathrm{C} / \mathrm{h}$, as slower cooling rates often result in long-term instability in the run conditions (e.g. Veksler et al., 2006; Veksler et al., 2008; Charlier and Grove, 2012). Conversely, although the much slower cooling rates of large igneous intrusions are not as well constrained, they are likely to be on the order of $10^{-7}{ }^{\circ} \mathrm{C} / \mathrm{h}$ 
(Cawthorn and Walraven, 1998). Published descriptions of unmixed silicate liquid microstructures preserved in natural systems with cooling rates intermediate between these two extremes are rare. Examples include glass quenched during drilling of the partially solidified crust of the Kîlauea Iki lava lake in Hawaii (Honour et al., 2019a) and microstructures in interstitial glass in naturally cooled tholeiitic dykes and sills (e.g. Philpotts, 1978; Philpotts, 1979; Philpotts, 1982).

In this study, we investigate emulsion microstructure preserved in the mesostasis of three basaltic dykes from the northeast of England. Using a conductive thermal model, we calculate the cooling rates across the dykes, while plagioclase aspect ratios and grain sizes are used to constrain the fluid dynamical regime during crystallisation. The cooling rates of the dykes are slower than can be routinely accessed through experimental petrology but are significantly faster than cooling rates in larger igneous intrusions. Hence, they provide an opportunity to constrain emulsion microstructures at intermediate cooling rates, and by studying samples across individual dykes and from intrusions of different sizes, we are able to investigate the nucleation and evolution of unmixed liquids as a function of cooling rate. Dykes show significant differences in the spatial variation of mineral grain shapes and sizes compared to tabular intrusions of similar thickness but with significantly shallower dips (i.e. sills), as a result of orientation-controlled differences in fluid dynamical regime during solidification (Holness et al., 2017). Following Holness et al. (2017), we argue that the Paleogene dykes of Northeast England are an exception to this general tendency, with microstructural characteristics indicative of sill-like fluid dynamical behaviour.

\section{GEOLOGICAL SETTING}

During the Palaeogene, a mantle plume in the North Atlantic (today located beneath Iceland; (Saunders et al., 1997) caused uplift and thinning of the NW European continental margin, resulting in the ascent of magmas to high crustal levels and emplacement of large igneous bodies in western Scotland (the Skye, Rum-Muck, Arran and Mull central complexes). 
Emplacement of the Mull Central Complex was associated with the intrusion of a large NWSE trending dyke swarm across western Scotland, northern England and into the North Sea (Harker and Clough, 1904; Sloan, 1971), extending at least $600 \mathrm{~km}$ from its source (Figure 1; Underhill (2009); Wall et al. (2010)). The swarm is dated between 58.04 and $60.56 \mathrm{Ma}$ (Mitchell et al., 1989; Chambers and Pringle, 2001) and is thought to be related to a large caldera collapse event (Macdonald et al., 2010).

Variations in magma propagation rate are thought to have caused the thickness and spacing of the Mull dyke swarms to increase with distance from their source (Jolly and Sanderson, 1995). Modern-day dyke intrusion events in the East African Rift and Iceland have propagation rates in the range $0.3-4.7 \mathrm{~km} / \mathrm{h}$ (e.g. Peltier et al., 2005; Wright et al., 2006; Ayele et al., 2009; Ágústsdóttir et al., 2016). Hence, we infer that the dykes of the Mull swarm took a minimum of 28 days to propagate $200 \mathrm{~km}$ from their source to the coast of Northeast England. Following the cessation of flow in the dykes, we assume that the magma crystallised as a closed system (e.g. Holness et al., 2017).

The basaltic dykes of the Mull swarm are geochemically analogous to the Central Mull tholeiitic magma (Kerr et al., 1999; Macdonald et al., 2010). They were classified based on their petrography and geochemistry by Holmes and Harwood (1929) and typical whole-rock compositions of the dykes investigated in this study are presented in Table 1. They have varying modal proportions of plagioclase, olivine and pyroxene, with a glassy matrix preserving evidence of liquid immiscibility (Holmes and Harwood, 1929). We focus on three dykes: (1) the Hartley North Dyke (which Teall (1884) termed the Collywell dyke) is finegrained with a sinuous strike through a host rock of shale with sandy bands (Jones, 1967; Land, 1974); (2) the Tynemouth Dyke, which cuts the Coal Measures sandstone at the current level of exposure (Land, 1974) and extends SE into the North Sea (Teall, 1884; Teall, 1889; Heslop and Smythe, 1910; Holmes and Harwood, 1929; Jones, 1967; Land, 1974); and (3) the Morpeth Dyke, which is fine-grained, has the highest measured density of the Palaeogene dykes of Northeast England (Teall, 1884; Heslop and Smythe, 1910; 
Holmes and Harwood, 1929) and is hosted within sandstone interbedded on a 10-20 m scale with

fissile

\begin{tabular}{cccc}
\hline \multicolumn{2}{c}{ Table 1 } & $\begin{array}{c}\text { Whole rock geochemistry of the Palaeogene dykes of Northeast } \\
\text { England, taken from Holmes and Harwood (1929). }\end{array}$ \\
\hline & $\begin{array}{c}\text { Talaidh-type dyke } \\
\text { (e.g. Hartley North) }\end{array}$ & $\begin{array}{c}\text { Brunton-type dyke } \\
\text { (e.g. Tynemouth) }\end{array}$ & $\begin{array}{c}\text { Salen-type dyke } \\
\text { (e.g. Morpeth) }\end{array}$ \\
\hline $\mathrm{SiO}_{2}$ & 51.10 & 50.81 & 50.41 \\
\hline $\mathrm{Al}_{2} \mathrm{O}_{3}$ & 16.75 & 15.70 & 15.14 \\
\hline $\mathrm{FeO}$ & 8.03 & 8.54 & 10.39 \\
\hline $\mathrm{MgO}$ & 5.89 & 6.41 & 6.57 \\
\hline $\mathbf{C a O}$ & 11.97 & 12.17 & 11.30 \\
\hline $\mathrm{Na}_{2} \mathbf{O}$ & 2.02 & 1.96 & 2.29 \\
\hline $\mathrm{K}_{\mathbf{2}} \mathrm{O}$ & 0.66 & 0.87 & 0.82 \\
\hline $\mathrm{TiO}_{2}$ & 0.96 & 0.81 & 1.30 \\
\hline $\mathbf{P}_{\mathbf{2}} \mathbf{O}_{5}$ & - & 0.10 & 0.15 \\
\hline $\mathbf{M n O}$ & 0.37 & 0.17 & 0.17 \\
\hline $\mathbf{M g \#}$ & 57 & 57 & 53 \\
\hline
\end{tabular}

mudstone.

\section{SAMPLES AND SAMPLE COLLECTION}

Samples were collected during fieldwork in July 2016, supplemented by additional samples from the Harker Collection of the Sedgwick Museum (University of Cambridge). The Hartley North Dyke was sampled $20 \mathrm{~m}$ from the N-S trending Collywell Bay sea wall, on the foreshore at low tide (Table 2). Here, the dyke has a strike of $105^{\circ}$, with a variable width (0.83-1.04 m; Figure 2c) and chilled margins. The Tynemouth Dyke is only exposed at low tide and samples were collected along the foreshore, north of the western end of the Tynemouth North pier, at the base of Castle Rock (Figure 2a-b). At this location, it is $3.18 \mathrm{~m}$ wide and strikes $103^{\circ}$, with undulating margins on a 0.1-0.2 $\mathrm{m}$ scale (Table 2). The Morpeth Dyke was sampled on the eastern bank of the Wansbeck, south-east of the North-Eastern Railway viaduct (Table 2), where it lies within a $5.25 \mathrm{~m}$ wide steep-sided gully perpendicular to the river. There is no visible outcrop and samples of olivine-rich basalt were obtained from scattered $>0.3 \mathrm{~m}$ diameter boulders and $<10 \mathrm{~cm}$ chips (Figure $2 \mathrm{~d}$ ). Teall's (1884) description of the Morpeth Dyke locality was published 34 years after the viaduct was built when there 
was significant building work along the bank of the Wansbeck; it is possible that it was quarried out and used for construction, thus creating the well-defined gully.

Table 2. Field locations of the Palaeogene dykes of Northeast England analysed in this study. SST = sandstone, $M S T=$ mudstone.

\begin{tabular}{ccccccc}
\hline Dyke & $\begin{array}{c}\text { Latitude } \\
(\mathrm{N})\end{array}$ & $\begin{array}{c}\text { Longitude } \\
(\mathrm{W})\end{array}$ & $\begin{array}{c}\text { Width } \\
(\mathrm{m})\end{array}$ & $\begin{array}{c}\text { Strike } \\
\left({ }^{\circ}\right)\end{array}$ & Host Rock & $\begin{array}{c}\text { No. of } \\
\text { samples }\end{array}$ \\
\hline $\begin{array}{c}\text { Hartley } \\
\text { North }\end{array}$ & $55^{\circ} 04^{\prime} 50.8^{\prime \prime}$ & $001^{\circ} 28^{\prime} 10.5^{\prime \prime}$ & $\sim 1.03$ & 105 & $\begin{array}{c}\text { SST } \\
\text { interbedded } \\
\text { with MST }\end{array}$ & 8 \\
\hline Tynemouth & $55^{\circ} 01^{\prime} 00.9^{\prime \prime}$ & $001^{\circ} 24^{\prime} 55.5^{\prime \prime}$ & $\sim 3.18$ & 103 & SST & 13 \\
\hline Morpeth & $55^{\circ} 10^{\prime} 13.6^{\prime \prime}$ & $001^{\circ} 39^{\prime} 45.1^{\prime \prime}$ & $<5.25$ & 122 & $\begin{array}{c}\text { interbedded } \\
\text { with MST }\end{array}$ & $\begin{array}{c}4 \text { (not in } \\
\text { situ) }\end{array}$ \\
\hline
\end{tabular}

Table 3. Petrographic measurements of the Palaeogene dykes of Northeast England. Distances from the dyke margins were measured from the north to south. Plagioclase grain size is reported as average apparent long axis, and shape is reported as the average apparent aspect ratio. $\mathrm{HC}=$ samples from the Harker Collection, University of Cambridge. * denotes the position within the dyke transect given in the catalogue of the Harker Collection.

\begin{tabular}{|c|c|c|c|c|c|c|c|}
\hline No. & $\begin{array}{c}\text { Distance } \\
\text { from the } \\
\text { north } \\
\text { margin } \\
(\mathrm{m})\end{array}$ & Position & $\begin{array}{c}\text { Modal } \\
\text { glass } \\
\%\end{array}$ & $\begin{array}{c}\text { Plag } \\
\text { average } \\
\text { apparent } \\
\text { long axis } \\
(\mu \mathrm{m})\end{array}$ & $\begin{array}{c}\text { Plag } \\
\text { average } \\
\text { apparent } \\
\text { aspect } \\
\text { ratio }\end{array}$ & $\begin{array}{l}\text { No. } \\
\text { plag/ } \\
\text { mm }^{2}\end{array}$ & $\begin{array}{c}\text { Largest } \\
\text { Fe-rich } \\
\text { Droplet } \\
(\mu \mathrm{m})\end{array}$ \\
\hline \multicolumn{8}{|c|}{ Hartley North Dyke; $1.03 \mathrm{~m} \pm 0.05 \mathrm{~m}$ wide } \\
\hline $\mathrm{H} 1$ & 0.05 & Margin & 18 & 189 & 6.0 & 30 & 1 \\
\hline $\mathrm{H} 2$ & 0.08 & Margin & 17 & 186 & 6.1 & 29 & $<2$ \\
\hline $\mathrm{H} 3$ & 0.23 & Centre & 19 & 239 & 5.5 & 17 & 3 \\
\hline $\mathrm{H} 4$ & 0.29 & Centre & 22 & 228 & 5.5 & 16 & 4 \\
\hline $\mathrm{H} 5$ & 0.32 & Centre & 20 & 231 & 4.6 & 14 & 3 \\
\hline $\mathrm{H} 6$ & 0.65 & Centre & 18 & 236 & 4.9 & 18 & 3 \\
\hline $\mathrm{H} 7$ & 0.86 & Margin & 16 & 223 & 5.3 & 18 & $<2$ \\
\hline $\mathrm{H} 8$ & 0.95 & Margin & 17 & 256 & 5.5 & 15 & $<2$ \\
\hline \multicolumn{8}{|c|}{ Tynemouth Dyke; $3.18 \mathrm{~m} \pm 0.20 \mathrm{~m}$ wide } \\
\hline $\mathrm{T} 1$ & 0 & Margin & 18 & 143 & 6.1 & 41 & 2 \\
\hline T2 & 0.2 & Margin & 20 & 173 & 5.7 & 16 & 4 \\
\hline T3 & 0.28 & Margin & 21 & 189 & 6.1 & 20 & 7 \\
\hline T4 & 0.7 & Centre & 23 & 245 & 4.7 & 9 & 5 \\
\hline T5 & 0.86 & Centre & 24 & 242 & 4.5 & 15 & 5 \\
\hline
\end{tabular}




\begin{tabular}{cccccccc}
\hline T6 & 1 & Centre & 26 & 234 & 4.6 & 10 & 11 \\
\hline T7 & 1.32 & Centre & 26 & 236 & 4.4 & 12 & 12 \\
\hline T8 & 1.42 & Centre & 25 & 230 & 4.4 & 14 & 13 \\
\hline T9 & 2.13 & Centre & 26 & 254 & 4.7 & 12 & 8 \\
\hline T10 & 2.48 & Centre & 25 & 244 & 4.8 & 12 & 6 \\
\hline T11 & 2.55 & Margin & 23 & 178 & 5.3 & 16 & 5 \\
\hline T12 & 2.76 & Margin & 22 & 167 & 6.1 & 21 & 7 \\
\hline T13 & 2.97 & Margin & 21 & 198 & 6.1 & 19 & 1 \\
\hline 20287 & HC & Centre* & 27 & 210 & 4.37 & 20 & - \\
\hline 20289 & HC & Centre* & 26 & 192 & 4.38 & 17 & - \\
\hline 20288 & HC & Centre* & 25 & 212 & 4.53 & 21 & - \\
\hline 20290 & HC & Margin* & 20 & 168 & 4.71 & 36 & - \\
\hline 14249 & HC & Margin* & 21 & 176 & 4.73 & 31 & - \\
\hline 4141 & HC & Margin* & 11 & 175 & 5.33 & 50 & - \\
\hline Morpeth Dyke; $<5.25$ m wide & & & & & \\
\hline 20303 & HC & Margin* & 25 & 175 & 4.91 & 43 & 9 \\
\hline 20302 & HC & Margin* & 29 & 150 & 4.77 & 39 & 8 \\
\hline 2362 & HC & Margin* & 21 & - & - & - & - \\
\hline 39782 & HC & Margin* & 19 & - & - & - & - \\
\hline
\end{tabular}

\section{Analytical methods}

Samples were analysed in the Department of Earth Sciences, University of Cambridge, using optical microscopy and a Quanta FEG 650 F scanning electron microscope (SEM), set to $10 \mathrm{kV}$ at spot 3 , with a $30 \mu \mathrm{m}$ aperture and a working distance of $10 \mathrm{~mm}$. Back-scatter electron (BSE) images were collected for the polished samples.

Average apparent aspect ratios of plagioclase grains were calculated by measuring the long and short axes of $>250$ crystals per sample from digital photomicrographs under crossed polars. All discernible plagioclase grains were measured in each photograph. Aspect ratios were calculated using ImageJ software. The $2 \sigma$ confidence interval of the average apparent aspect ratio was calculated using the bootstrap method (James et al., 2013) since the shape of the underlying distribution is unknown. Plagioclase grain sizes were also calculated using the average of the long axis length of $>250$ plagioclase grains. Fe-rich droplet diameters were measured using CorelDrawX9 from BSE images. All discernible Fe-rich droplet diameters were measured in each photograph.

Preliminary EPMA (electron probe micro-analysis) data were collected on plagioclase crystals in our samples using a CAMECA SX-100 electron microprobe with five WDS 
spectrometers at the Department of Earth Sciences, University of Cambridge. The instrument uses PeakSight software with ZAF correction. Appropriate natural and synthetic primary standards were used. Plagioclase compositions were analysed at $15 \mathrm{kV}, 10 \mathrm{nA}$ with a focused beam; $\mathrm{Na}$ and $\mathrm{Si}$ were analysed for 10 s on peak, $\mathrm{Al}$ for $20 \mathrm{~s}, \mathrm{Ca}, \mathrm{Mg}$, and $\mathrm{K}$ for 30 $\mathrm{s}$, and $\mathrm{Ti}$ and Fe for $60 \mathrm{~s}$. Relevant mineral and glass secondary standards were run at regular intervals to check for precision and reproducibility.

\section{RESULTS}

\section{Petrography}

The Hartley North Dyke is dominated by a matrix of fine-grained plagioclase, clinopyroxene and glass, with variable modal Fe-Ti oxide (Figure 3a). The amount of glass increases from 16 vol. $\%$ on the chilled margins to 22 vol. $\%$ in the centre of the intrusion. The average matrix plagioclase long axis length (Table 3) increases towards the dyke centre, from $189 \mu \mathrm{m}$ to $231 \mu \mathrm{m}$, and the average apparent aspect ratio decreases from 6.0 to 4.6 (Figure 4a; Table 3). Rare, large (<2 $\mathrm{mm} \times 0.8 \mathrm{~mm})$ plagioclase phenocrysts with zoned rims are present throughout. Clinopyroxene is fine-grained on the chilled margins $(<10 \mu \mathrm{m})$ but reaches 100 $\mu \mathrm{m}$ diameter in the dyke centre where the crystals tend to form small clusters. Spherical amygdales filled with calcite and silica are abundant (0.5-1.8 $\mathrm{mm}$ in diameter), particularly in the centre of the dyke.

The Tynemouth Dyke is dominated by a fine-grained matrix of elongated plagioclase laths, clinopyroxene, oxides and glass (Figure $3 \mathrm{~b}-\mathrm{c}$ ) with rare olivine grains, typically $<50 \mu \mathrm{m}$ in diameter. The glass distribution is patchy but the average glass mode increases from 18 vol. \% on the chilled margin to 26 vol. \% in the centre of the intrusion. The glass in the dyke centre is commonly devitrified. The average apparent aspect ratio of the matrix plagioclase (Figure 4) decreases from 5.4 on the chilled margins to 3.9 in the centre (Table 3), as does the relative number of matrix plagioclase grains per unit area. The dyke contains large plagioclase phenocrysts $(<9 \times 4 \mathrm{~mm})$ with sharply-defined, $<0.5 \mathrm{~mm}$ wide irregular rim zones 
and concentrically-arranged melt inclusions that outline internal growth zones. The anorthite number (molar $\mathrm{Na} /[\mathrm{Na}+\mathrm{Ca}]$ ) of the large plagioclase phenocrysts decreases from the centre to the rims of the crystals (Figure S1). The number of plagioclase phenocrysts increases towards the intrusion centre, where they form polycrystalline clusters with a shared outer rim zone; the plagioclase rim zone is absent on crystal faces adjacent to pockets of glass within the polycrystalline cluster (Figure 3c). The grain size range of matrix plagioclase in the Tynemouth Dyke broadens towards the intrusion centre and the average long axis length increases from $143 \mu \mathrm{m}$ to $236 \mu \mathrm{m}$ (Table 3). Clinopyroxene grains are small $(<80 \mu \mathrm{m}$ diameter) and isolated in the matrix on the chilled margins, whereas in the centre of the dyke they are larger ( $<150 \mu \mathrm{m}$ diameter) and form clusters or partially enclose plagioclase grains. Fe-Ti oxide grains are $<50 \mu \mathrm{m}$ across and are typically found in the mesostasis. Spherical amygdales filled with calcite and silica are irregularly distributed throughout the Tynemouth Dyke, increasing in number and size towards the centre.

The Morpeth Dyke is characterised by a matrix of elongated plagioclase laths, clinopyroxene, olivine, oxides and glass (Figure 3d). The glass mode is analogous to the Tynemouth and Hartley North Dykes at 25 vol.\%. Although spatial variations in matrix plagioclase average apparent aspect ratio and grain size could not be quantified due to the lack of outcrop, the long axis length in our samples reaches $\sim 500 \mu \mathrm{m}$, while the average plagioclase apparent aspect ratio is 4.8 . Large plagioclase phenocrysts $(3 \times 2 \mathrm{~mm})$ are rare but have strongly zoned rims and melt inclusions in their core. Clinopyroxene is evenly distributed, with grain diameters ranging between 50-200 $\mu \mathrm{m}$. Rare olivine grains (100-300 $\mu \mathrm{m}$ in diameter) form small monomineralic clusters, typically comprising 3-4 grains. Spherical amygdales filled with calcite and silica are present in all of our samples.

\section{Immiscibility microstructures}

Evidence of unmixing of the interstitial liquid of the Palaeogene dykes of Northeast England was first reported by Philpotts (1982). The whole rock chemistry means that the Fe-rich immiscible liquid is the minor phase, while the Si-rich conjugate forms the major phase (i.e. 
Fe-rich droplets are dispersed within a continuous Si-rich liquid). The glass in the dykes is generally altered, with increasing devitrification towards the centres, resulting in poorer microstructural preservation. However, droplets of immiscible Fe-rich material are always present in the mesostasis, regardless of sample position within the dyke or the dyke width (Figure 5a-f). Where glass is still present, the Fe-rich droplets are spherical to sub-spherical, with a high refractive index and a white-to-brownish colour in plane polarised light. Where the glass is fully or partially devitrified, the droplets are framboidal (Figure 5).

The Fe-rich droplets are larger (up to $20 \mu \mathrm{m}$ in diameter) and more abundant in the centre of the dykes than at their margins. On the margins, the Fe-rich droplets are preferentially attached or proximal to plagioclase grains. Towards the dyke centres, the Fe-rich droplets show no preferential association with any crystal phase and there is an increased prevalence of isolated droplets (i.e. droplets that appear unconnected to any crystal phase in 2D section). Where Fe-rich droplets are attached to plagioclase grains, they have apparent wetting angles $>90^{\circ}$. They are not found adjacent to mafic phases and we found no evidence of two droplets coalescing (i.e. no Fe-rich droplets with 'figure-of-eight' shapes).

There are variations in the emulsion microstructure between the three dykes. In the Morpeth Dyke, the Fe-rich droplets are larger and have a higher number density than in the Tynemouth and Hartley North Dykes (even in samples from the margin of the dyke; Figure 6). Fe-rich droplets in the Hartley North Dyke are the least abundant and the smallest of those in the three dykes (Figure 6g-i).

\section{DISCUSSION}

\section{The crystallisation regime}

The shape of plagioclase grains grown under interface-controlled conditions is a function of crystallisation time (Holness, 2014). In vigorously convecting magma within a tabular body, plagioclase crystals grow in suspension and the resultant averaging of the thermal history of each grain means that their shape is invariant across the width of the intrusion (Holness, 
Neufeld et al. 2017). In contrast, if the crystallising magma is either static or weakly convecting, solidification is dominated by the nucleation and growth of crystals on inwardspropagating solidification fronts: in such bodies plagioclase average apparent aspect ratio decreases from the intrusion margins towards the centre (Holness et al., 2017). Assuming diffusive heat loss, the average apparent plagioclase aspect ratio at any point across a tabular intrusion that solidified by the inwards-propagation of solidification fronts is given by (Holness 2014):

plagioclase aspect ratio $=(\log ($ cooling time in years $)-6.34) /(-1.79)$

Consequently, we can use the spatial variation of plagioclase grain shape to test whether vigorous convection occurred during crystallisation of the investigated dykes.

The highest plagioclase average apparent aspect ratios are observed on the margins of the Hartley North and Tynemouth Dykes, while the lowest ratios are measured in their centres. The plagioclase average apparent aspect ratios across the Hartley North and Tynemouth Dykes match the trends predicted for non-convecting magma bodies using eq. 1, but are systematically off-set to higher values (Figure 4). It is well-known that aspect ratio decreases as crystallisation proceeds, due to the effects of impingement (Martin et al., 1987; Pupier et al., 2008; Schiavi et al., 2009; Applegarth et al., 2013) but the Holness (2014) relationship between plagioclase grain shape and cooling timescales described in eq. 1 was developed using fully-solidified dolerites. We suggest that the relatively high aspect ratios observed in our samples may be a consequence of the significant volume of uncrystallised material comprising the mesostasis: the average apparent aspect ratio of the plagioclase did not attain the expected low values as crystallisation was incomplete. We also note that there are a number of spherical amygdales in the dykes, which suggest that magma degassed during crystallisation. Devolatilisation could drive plagioclase oversaturation (Yoder et al., 1957; Hort, 1998) and an increase in plagioclase growth rate, which might also result in higher average apparent aspect ratios than predicted by the Holness (2014) relationship (Figure 4). 
In addition to differences in the spatial variation of plagioclase grain shape in convecting and non-convecting systems, the average grain size is larger and the range of grain sizes is narrower in convecting tabular intrusions, relative to non-convecting intrusions of the same width (i.e. with similar cooling timescales; Holness et al. (2017)). Figure 7 shows the cumulative frequency of the plagioclase long axis length from the centre and margin of the Hartley North and Tynemouth Dykes, as well as grain size data from previously identified convecting (a $3.7 \mathrm{~m}$ wide basaltic dyke from the Isle of Mull) and non-convecting intrusions (the $3.5 \mathrm{~m}$ thick Traigh Bhàn na Sgùrra sill of the Isle of Mull), which have similar widths to the Northeast England intrusions (i.e. within an order of magnitude; Holness et al., 2017). The cumulative frequency distributions of plagioclase long axis length from the centre and margin of the Tynemouth and Hartley North Dykes are similar to those of the non-convecting Traigh Bhàn na Sgùrra sill, rather than the convecting dyke. Together with the spatial variation of plagioclase grain shape, these data suggest that crystallisation in the Northeast England dykes was dominated by the inwards propagation of solidification fronts, in agreement with Holness et al. (2017), who identified non-convective crystallisation in the Moneyacres dyke in Ayrshire (another member of the Mull dyke swarm). The absence of convection following dyke propagation may have been due to a high crystallite load, resulting in a high magma viscosity (Holness et al., 2017).

We consider it unlikely that silicate liquid unmixing occurred during dyke propagation: magma compositions only approach the silicate liquid binodal after significant differentiation (i.e. likely after crystallisation of groundmass plagioclase); we see no evidence of bimodal melt inclusion populations in large plagioclase phenocrysts (indicative of the trapping of two immiscible liquids c.f. Jakobsen et al. (2011); Fischer et al. (2016), although this may be masked by devitrification); and preliminary geochemical transects across the large plagioclase phenocrysts show no evidence of decreasing $\mathrm{TiO}_{2}$ concentrations towards the rim, which is indicative of liquid unmixing during crystallisation (c.f. Humphreys (2011); 
Figure S1). Unmixing therefore occurred in a static magma, once matrix plagioclase had started to crystallise.

\section{Thermal modelling of cooling rate}

As the magma in the dykes was static (or only weakly convecting) during solidification, we use a 1D thermal model to calculate the cooling rate at different positions across the intrusions for comparison with the size and abundance of unmixed Fe-rich droplets. The cooling rate of any sample from a tabular basaltic intrusion can be approximated assuming conductive in situ heat transfer into the host rock, following the approximation of (Holness et al., 2012):

$\tau=0.1 \frac{w^{2}}{K}\left(1+\cos \left(\frac{2 \pi z}{w}\right)\right)$

where $\tau$ is the time taken to cool from $1200^{\circ} \mathrm{C}$ to $1000^{\circ} \mathrm{C}$ (the assumed temperature range of crystallisation, following Cashman (1993); and Holness et al. (2012)), $z$ is the position within the body measured from the centre (in metres), $w$ is the total intrusion thickness (in metres) and $k$ is thermal diffusivity $\left(\mathrm{m}^{2} / \mathrm{s}\right)$. We assume a far-field host rock temperature of $0^{\circ} \mathrm{C}$ and set $k$ to $4.8 \cdot 10^{-7} \mathrm{~m}^{2} / \mathrm{s}$ based on thermal diffusivity measurements of basalt at $1000^{\circ} \mathrm{C}$ (Hartlieb et al., 2016).

Our 1D cooling model suggests the Hartley North Dyke took 5 days to crystallise in the centre and 0.5 days near the margins (defined in Table 3), corresponding to average cooling rates of $\sim 1.7^{\circ} \mathrm{C} / \mathrm{h}$ and $\sim 16.7^{\circ} \mathrm{C} / \mathrm{h}$, respectively. The Tynemouth Dyke took 43 days to crystallise in the centre and 0.5 days near the margins (defined in Table 3), corresponding to average cooling rates of $\sim 0.2^{\circ} \mathrm{C} / \mathrm{h}$ and $\sim 17^{\circ} \mathrm{C} / \mathrm{h}$, respectively. Assuming the Morpeth Dyke was no wider than the gully in which it was sampled, the centre is predicted to have had a maximum cooling time of 117 days, with an associated average cooling rate of $\sim 0.1^{\circ} \mathrm{C} / \mathrm{h}$. 


\section{The effect of cooling rate on emulsion behaviour}

In a static regime, the microstructure of magmatic emulsions is controlled chiefly by temperature and time (e.g. Martin and Kushiro, 1991). Additional factors that can affect microstructural evolution include composition, pressure and $\mathrm{fO}_{2}$ (e.g. Charlier and Grove, 2012). However, these are second-order variables (Martin and Kushiro, 1991) and are unlikely to vary significantly between compositionally similar mafic dykes (Table 1) emplaced at comparable depths.

\section{Nucleation}

Compositional boundary layers can develop at the interface between crystals and their host liquids; the thickness of these layers depends on the crystal growth rate, the elemental diffusion rates within the liquid and the relative motion of crystals and their surrounding liquid (Levich, 1962; Zellmer et al., 2016). The development of these compositional boundary layers can promote the onset of liquid unmixing, causing Fe-rich droplets to preferentially nucleate on (or near) plagioclase grains (Philpotts, 1981). Compositional gradients around crystals are best developed during rapid crystal growth and we would therefore expect Ferich droplets to have a greater association with plagioclase crystals at higher cooling rates. This accounts for the greater number of Fe-rich droplets attached to plagioclase crystals in the rapidly cooled margins of the Hartley North and Tynemouth Dykes, relative to their slower cooler centres.

Considering both samples from different places within the same dyke and samples from different dykes, we find that slower cooling rates correlate with increased numbers of Fe-rich droplets in the interstices (including both heterogeneously nucleated attached droplets and homogeneously nucleated isolated droplets). This is at odds with the experiments of Martin and Kushiro (1991), which contain more droplets at higher cooling rates, leading the authors to conclude that slow cooling promotes increased droplet coalescence rather than a decrease in nucleation rate. We suggest that the disparity between our observations and these experimental results can be explained by magma cooling rates at the dyke margins 
being fast enough that there is insufficient time for droplets to nucleate before the glass transition temperature was reached. Additionally, the smaller grain size and higher aspect ratios of the network-forming plagioclase grains near the intrusion margins (i.e. at high cooling rates) reduced the size of the interstitial liquid pockets, impeding nucleation and resulting in fewer Fe-rich droplets (e.g. Putnis and Mauthe, 2001; Holness and Sawyer, 2008).

The Morpeth Dyke has the most Fe-rich bulk composition of our samples and the Hartley North Dyke is the most Fe-poor (Table 1). The bulk FeO content of the dykes correlates with the size and abundance of the Fe-rich droplets, and thus the volume fraction of Fe-rich immiscible liquid. This agrees with the experimental results of Charlier and Grove (2012), which demonstrate that differing whole rock compositions affect the shape and size of the silicate liquid immiscibility field and thus the relative volumes of the two immiscible liquids: the abundance of the Fe-rich liquid generally increases with total $\mathrm{FeO}$ in the bulk melt (other elements such as $\mathrm{P}$, alkalis and volatiles also have a minor affect the size of the binodal; e.g. Lester et al. (2013)).

Only whole-rock data are available for the dykes in this study; these consistently have an $\mathrm{Mg \#}$ (molar $\mathrm{Mg} /\left(\left[\mathrm{Mg}+\mathrm{Fe}_{\text {total }}\right)\right.$ of $\sim 57$ (Table 1), which is significantly higher than the $\mathrm{Mg \#}$ from existing experiments quantifying the silicate liquid immiscibility field (e.g. bulk liquid compositions studied by Charlier and Grove (2012) had Mg\# of 29-36). Although the interstitial liquid in the dykes likely has a lower Mg\# than their bulk composition (due to olivine and clinopyroxene crystallisation), it is not possible to quantitatively constrain the position of the dyke magmas on a binodal using the available geochemical data. This could be achieved with further geochemical work extending the silicate liquid immiscibility experimental database over a greater range of starting compositions.

\section{Emulsion coarsening}

In our samples, slower cooling rates are associated with larger Fe-rich droplets and a wider droplet size distribution, both across a single intrusion and between intrusions. For example, 
across the Tynemouth Dyke, a three orders of magnitude increase in cooling rate correlates with an order of magnitude increase in droplet size (Figure 8) and a widening of the droplet size distribution. Similarly, droplets are larger and more variable in size in the centre of the slower cooling Tynemouth Dyke than in the centre of the smaller, and therefore faster cooling, Hartley North Dyke. This implies Fe-rich droplet size does not scale linearly with cooling rate and supports previous experimental work that suggests Fe-rich droplet size and cooling rate are related by an exponential law (Martin and Kushiro, 1991). Regressing the data of Martin and Kushiro (1991) suggests that variations in Fe-rich droplet size are related to the cooling rate of tholeiitic basalts via:

$y=73.159 e^{-0.646 x}$

where $\mathrm{x}$ is the average of the 5 largest diameter $(\mu \mathrm{m})$ Fe-rich droplets in each sample and $\mathrm{y}$ is cooling rate $\left({ }^{\circ} \mathrm{C} / \mathrm{h}\right)$.

Using the largest Fe-rich droplets in the centre of the Hartley North Dyke, eq. 3 predicts a cooling rate of $5.5^{\circ} \mathrm{C} / \mathrm{h}$, which is faster than the $1.7^{\circ} \mathrm{C} / \mathrm{h}$ calculated using the simple $1 \mathrm{D}$ cooling model of Holness et al. (2012). While these estimates are comparable within an order of magnitude, the disparity could be caused by factors other than cooling rate controlling the Fe-rich droplet size. The coarseness of Fe-rich droplets in unmixed silicate melts is a function of diffusion-controlled droplet growth, Ostwald ripening and/or coalescence. Diffusion-controlled Fe-rich droplet growth is driven by widening of the silicate liquid immiscibility binodal during cooling or chemical equilibration (Honour et al., in revision). Ostwald ripening is driven by differences in the surface curvature of the Fe-rich droplets as a function of size (Ostwald, 1897; McNaught, 1997). Coalescence occurs as droplets collide and is a function of droplet radius, viscosity, density and the interfacial energy (Yao et al., 2005). Recent progress in defining the binodal for silicate liquid immiscibility (Charlier and Grove, 2012) and investigating the microstructure of unmixing magmas with constant cooling rates (Farr et al., 2017; Honour et al., in revision) indicates that liquid composition may also affect droplet size due to an expansion or reduction in the volume of Fe-rich liquid. 
The largest Fe-rich droplets in our samples from the Tynemouth and Morpeth Dykes are bigger than those measured by Martin and Kushiro (1991). Their model is not calibrated for cooling rates $<2^{\circ} \mathrm{C} / \mathrm{h}$ and thus does not adequately capture the range of cooling rates that our 1D cooling model predicts for the Northeast England dykes. Combining our new data for the Northeast England dykes with the experiments of Martin and Kushiro (1991) extends the range of cooling rates (Figure 8), and we find that the relationship between droplet size and cooling rate $\left({ }^{\circ} \mathrm{C} / \mathrm{h}\right)$ is better expressed by the power law regression:

$y=84.681 x^{-2.461}$

where $\mathrm{x}$ is the average of the 5 largest diameter $(\mu \mathrm{m})$ Fe-rich droplets in each sample.

At fast cooling rates $\left(>5^{\circ} \mathrm{C} / \mathrm{h}\right)$ and low proportions of interstitial liquid on the dyke margins (Table 3), the time between the liquid intersecting the binodal and reaching the glass transition could be $<60 \mathrm{~h}$, based on the known apex temperature of the silicate liquid immiscibility binodal $\left(1025^{\circ} \mathrm{C}\right.$; Charlier and Grove (2012)) and the glass transition temperature (experimentally determined to be $725^{\circ} \mathrm{C}$ for a Kîlauea basalt from the Kîlauea Iki lava lake; Ryan and Sammis (1981)). Note, this is likely a maximum timescale as the glass transition temperature increases with faster cooling rates (Giordano et al., 2005) and the Kīlauea Iki lava lake cooling rate was three orders of magnitude slower than even the central regions of the dykes studied here (Helz et al., 2014). The results of Honour et al., (2019b) show that $60 \mathrm{~h}$ is insufficient time for coarsening of the Fe-rich droplets to be a result of Ostwald ripening.

In the dyke centres, where cooling rates were slower and there was a higher proportion of interstitial liquid, the coarser droplet size may be a consequence of diffusive processes (either Ostwald ripening or droplet growth driven by chemical equilibration as the binodal widens down-temperature) and/or coalescence. Such diffusive processes are accelerated by a decrease in viscosity of the Si-rich immiscible liquid due to high volatile content, prior to degassing (Kohn, 2000). We do not see rapid increases in the Fe-rich droplet size across 
the dyke width (Table 3), as would be expected if droplet coarsening were driven by coalescence. Hence, we suggest that diffusion-controlled growth is the most probable coarsening mechanism, in agreement with the experimental results of Honour et al., (2019b), who show that droplet coalescence is negligible in rapidly quenched ferrobasaltic experiments.

\section{Microstructures}

In many natural examples of rapidly-cooled basaltic rocks containing evidence of immiscibility, the faces of plagioclase grains parallel with the long axis (e.g. (100) and (010)) and in contact with glass are not planar but are decorated with micron-scale pillar-like structures that are invariably enclosed by Fe-rich droplets of a slightly larger diameter (Philpotts, 1981). Philpotts (1981) suggests that pillar formation post-dates the attachment of the Fe-rich droplets, with the droplet destabilising the planar crystal face due to local enhancement of plagioclase growth where mass diffusion is faster through the low viscosity Fe-rich liquid. This hypothesis is supported by the enrichment of the pillars in elements with a low concentration in the Fe-rich immiscible liquid, such as $\mathrm{Na}, \mathrm{Al}$ and $\mathrm{Si}$ (Honour et al., 2019b). No plagioclase pillars are observed in our Northeast England dykes, which is surprising given that Fe-rich droplets are attached to plagioclase grains in all three intrusions. On the dyke margins, the cooling rate was $>10^{\circ} \mathrm{C} / \mathrm{h}$, which is faster than in experimental studies and other natural samples where pillars have been observed (i.e. lava flows and lava lake crust; Charlier and Grove (2012)). One possibility is that observable pillars are absent in our samples from dyke margins because the plagioclase growth rate (likely $\sim 5 \times 10^{-12} \mathrm{~m} / \mathrm{s}$; Kirkpatrick (1977)) was too slow to permit pillar development before the system cooled through the glass transition. However, this cannot explain the absence of pillars in the centre of the dykes where cooling rates were slower. An alternative explanation may be that the nucleation of the Fe-rich droplets on the plagioclase growth faces occurred too late in the growth history for significant pillar formation. 


\section{CONCLUSIONS}

1. Plagioclase aspect ratios and grain sizes are consistent with the magma in the Tynemouth and Hartley North Dykes being static, or only weakly convecting, during crystallisation.

2. 1D thermal modelling assuming conductive heat transfer suggests that the Hartley North (1.03 m wide), Tynemouth (3.18 m wide) and Morpeth (<5.25 m wide) Dykes took 5,43 , and $<117$ days to crystallise, respectively. This equates to cooling rates in the dyke centres between 0.1 and $1.7^{\circ} \mathrm{C} / \mathrm{h}$.

3. The emulsion microstructure varies as a function of cooling rate, both between intrusions and within individual intrusions. Slower cooling rates and increasing size of interstitial melt pockets correlate with increasing Fe-rich droplet number density.

4. Both the largest Fe-rich droplet size and the range of droplet sizes increase at slower cooling rates. The size of the largest droplets and the dyke cooling rate are related by the expression $y=84.681 x^{-2.461}$. Hence, our study demonstrates that Fe-rich droplet size correlates with the cooling rate of igneous intrusions of similar compositions.

\section{ACKNOWLEDGEMENTS}

Many thanks to Brian Young and the late Henry Emeleus for advice on fieldwork localities. We are grateful to the Sedgwick Museum at the University of Cambridge for the loan of samples. We would like to thank Ilya Veksler and two anonymous reviewers for their thoughtful and constructive comments. We also wish to thank Giulio Lampronti and Iris Buisman at the University of Cambridge for assistance with SEM analyses. VCH was funded by a Natural Environmental Research Council Doctoral Training Programme studentship project (Grant Ref: NE/L002507/1) and MJS was funded by a Junior Research Fellowship at Christ's College, Cambridge. 


\section{FIGURE CAPTIONS}

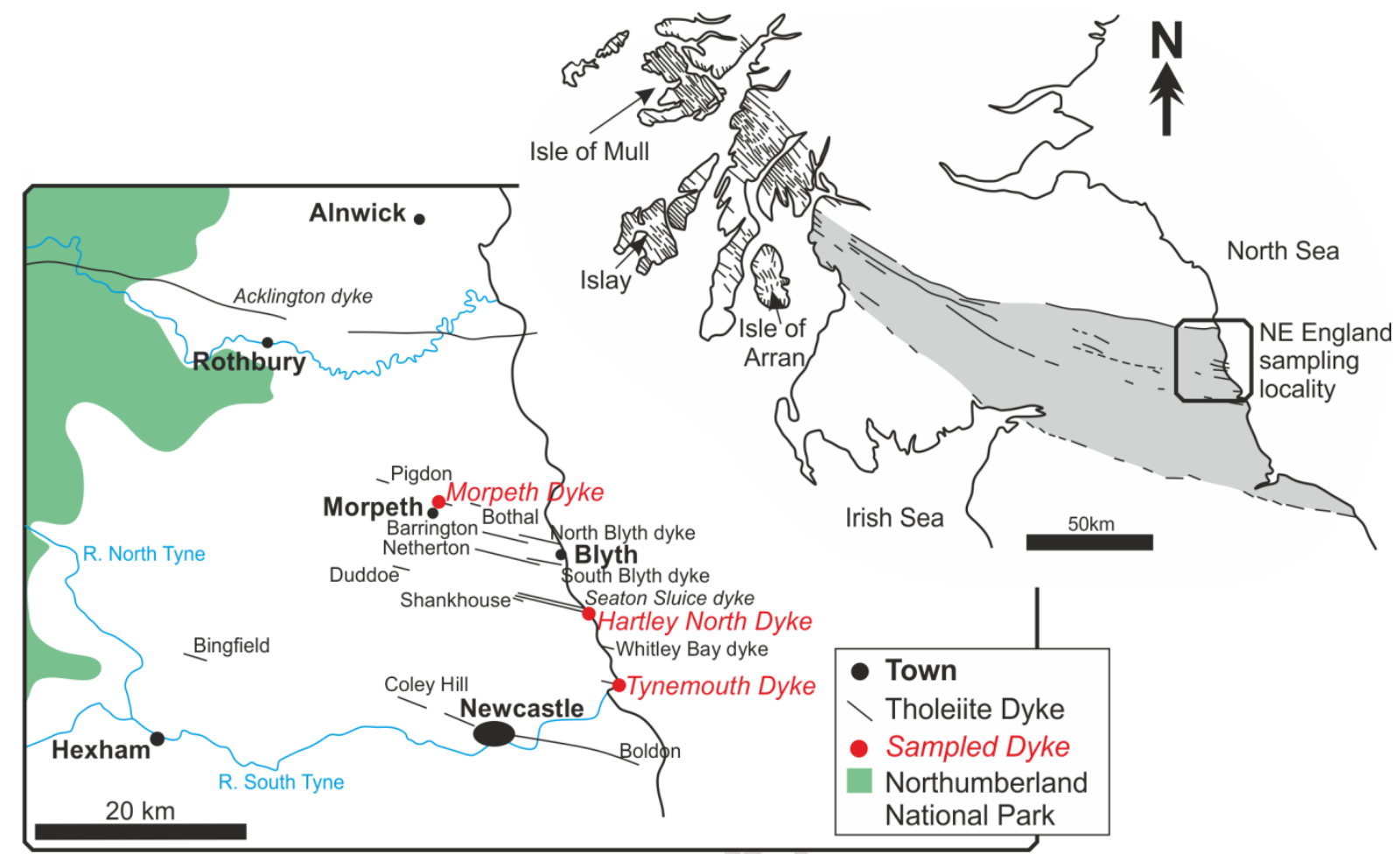

FIG. 1. Overview of the Mull dyke swarm, together with the location of the dykes examined here. Adapted from Holmes and Harwood (1929). 

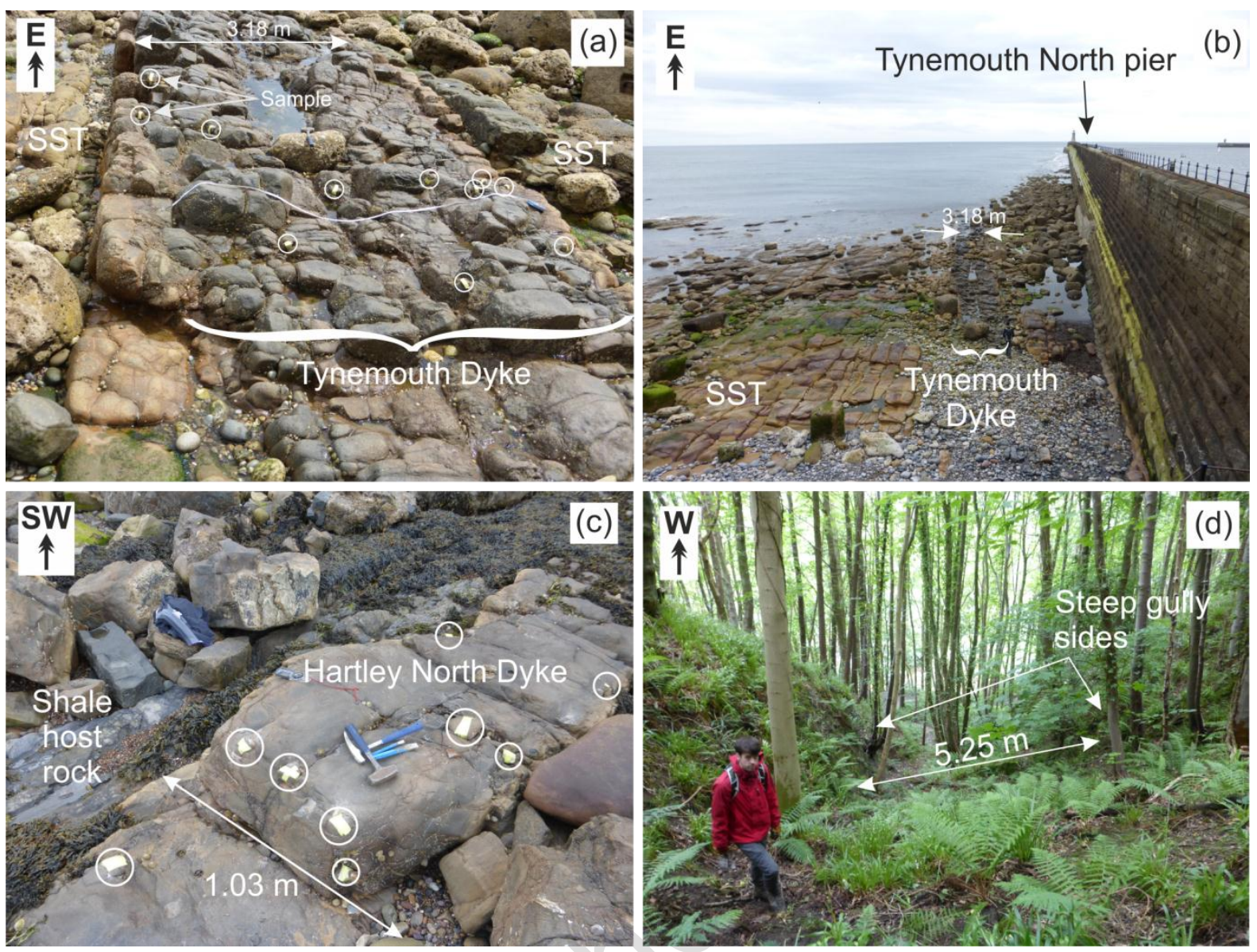

FIG. 2. Field photographs of the sampling locations in this study. a) Tynemouth Dyke, sampling localities outlined with white circles; b) Tynemouth Dyke exposed north of the Tynemouth North pier; c) Hartley North Dyke sampling localities outlined with white circles; d) the Morpeth Dyke locality. 

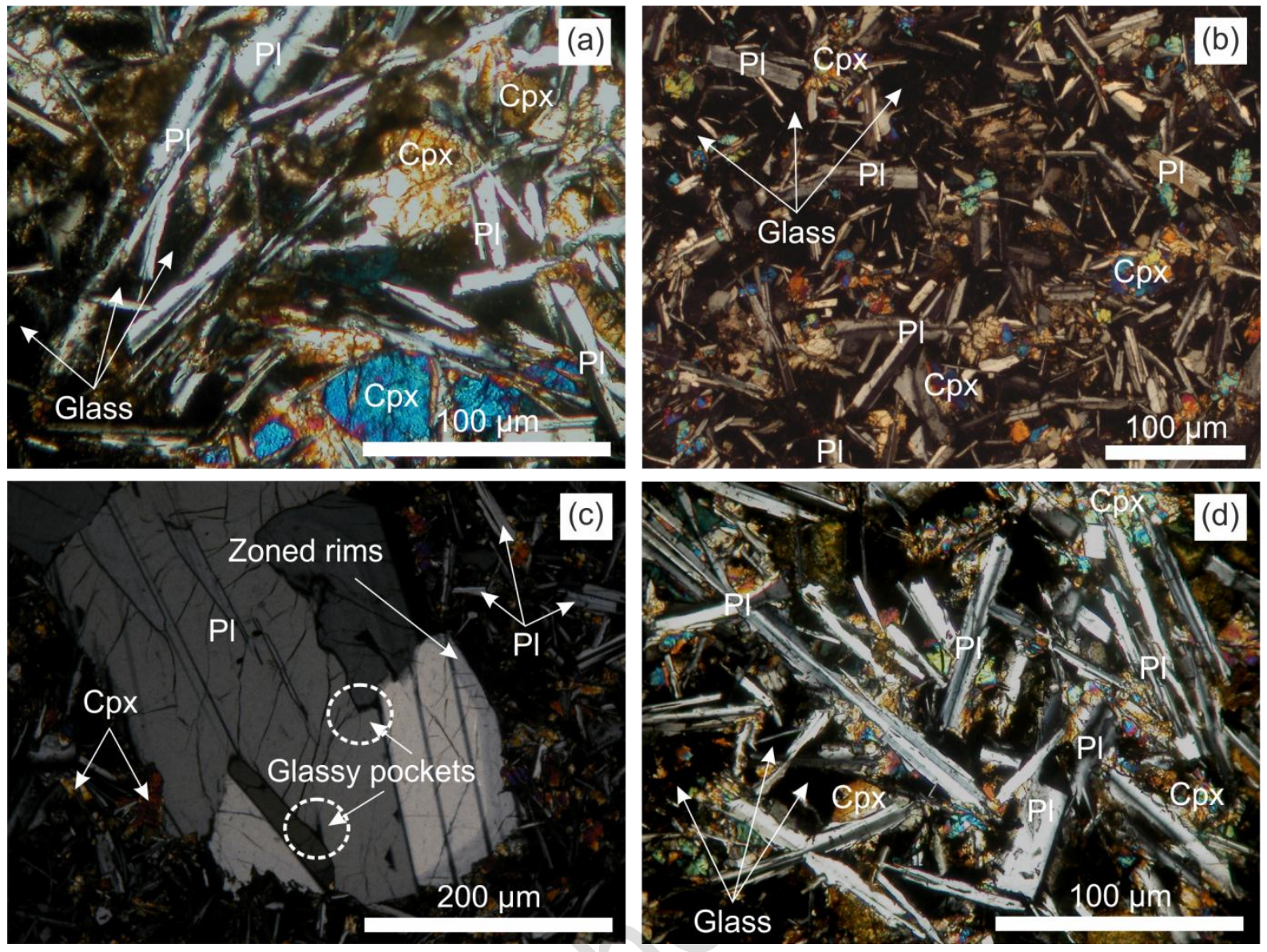

FIG. 3. Crossed polars (XPL) photomicrographs of the Palaeogene dykes of Northeast England; (a) Centre of the Hartley North Dyke; (b) Centre of the Tynemouth Dyke with abundant plagioclase laths and a glassy mesostasis; (c) A cluster of zoned plagioclase phenocrysts in the centre of the Tynemouth Dyke; (d) Margin of the Morpeth Dyke (spatial information taken from the catalogue of the Harker Collection).
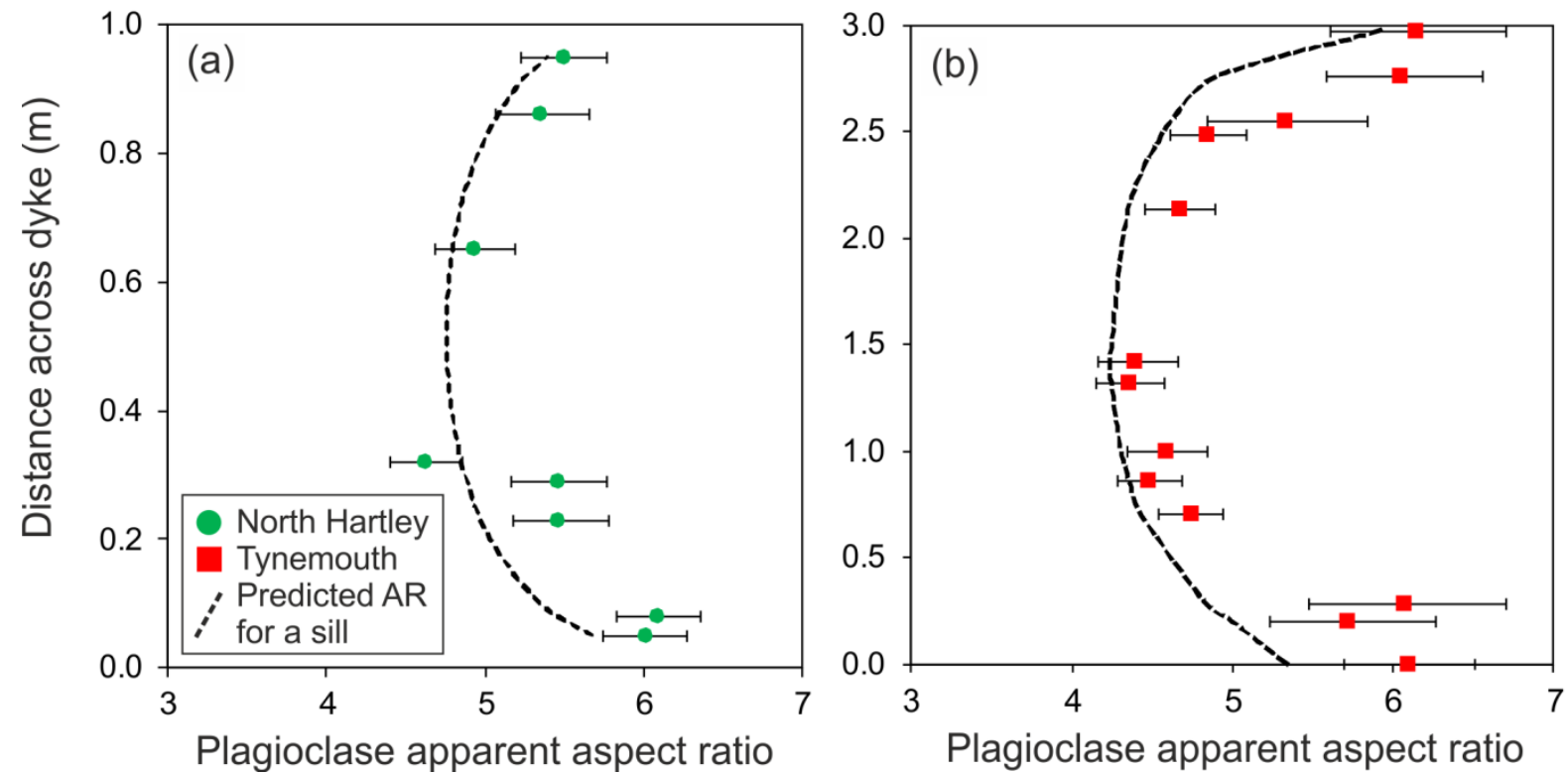

FIG. 4. Average apparent plagioclase aspect ratios measured across the (a) Hartley North Dyke; (b) Tynemouth Dyke. The dashed line is the predicted average apparent aspect ratio (AR) trend following Holness (2014). 

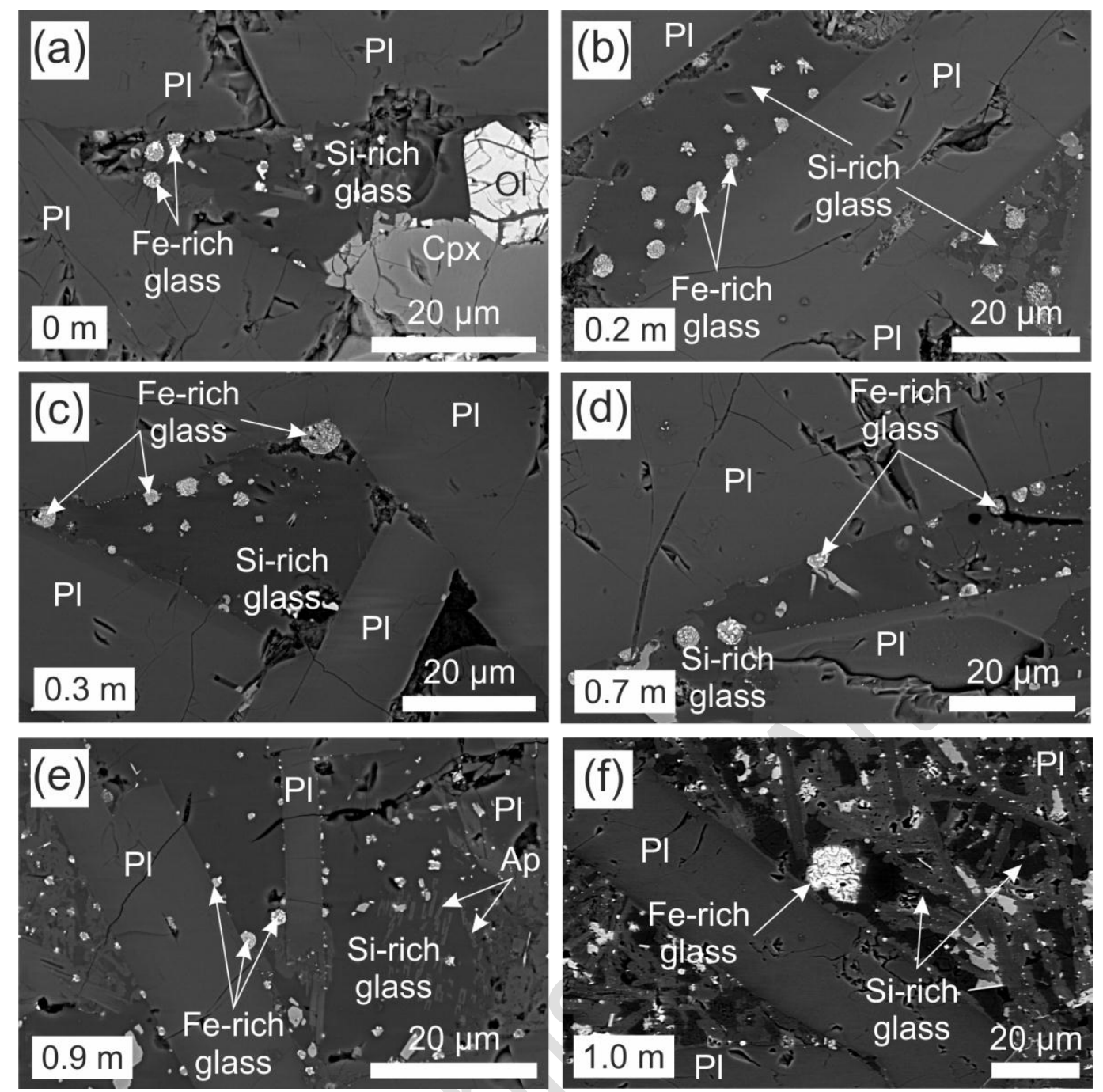

FIG. 5. BSE images of the Fe-rich emulsion in the Tynemouth Dyke; (a-f) show a progressive transect southwards towards the dyke's centre, with exact distance from the north margin given in the bottom left of each photo. Note the predominance of Fe-rich droplets that are attached to plagioclase, compared to those isolated in the glass, particularly close to the margin. 

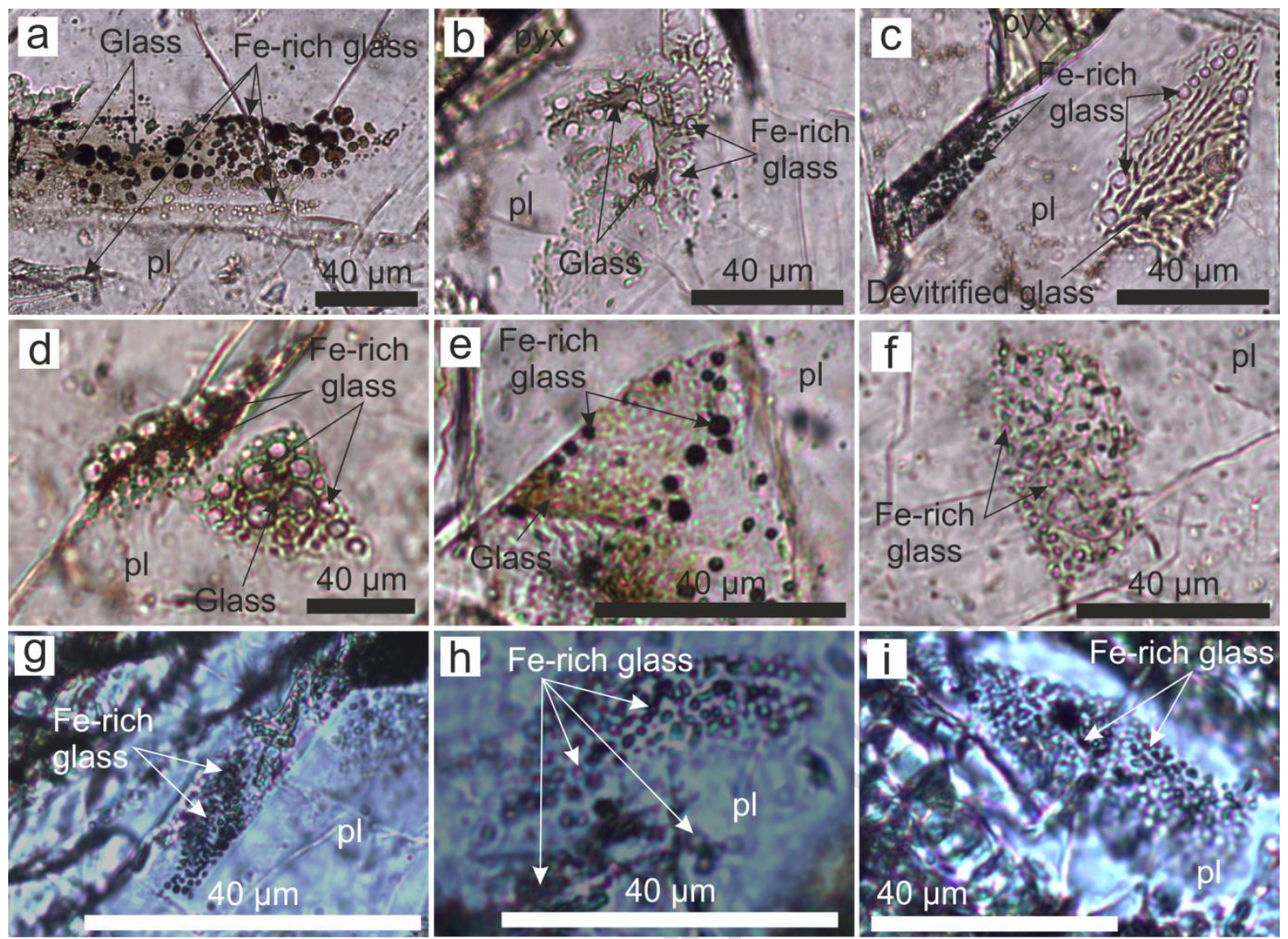

FIG. 6. Plane polarised light (PPL) images of emulsion microstructures for all three dykes, showing the Fe-rich droplets in the glassy mesostasis. The glass of the mesostasis is commonly brown, with the Fe-rich droplets ranging from white to dark brown. The Fe-rich droplets are typically attached to plagioclase. (a-c) Sample from the margin of the Morpeth Dyke (Table 3); ( $d$-e) Sample from the centre of the Tynemouth Dyke; (f) Sample from the margin of the Tynemouth Dyke; ( $g$-i) Sample from the margin of the Hartley North Dyke. 


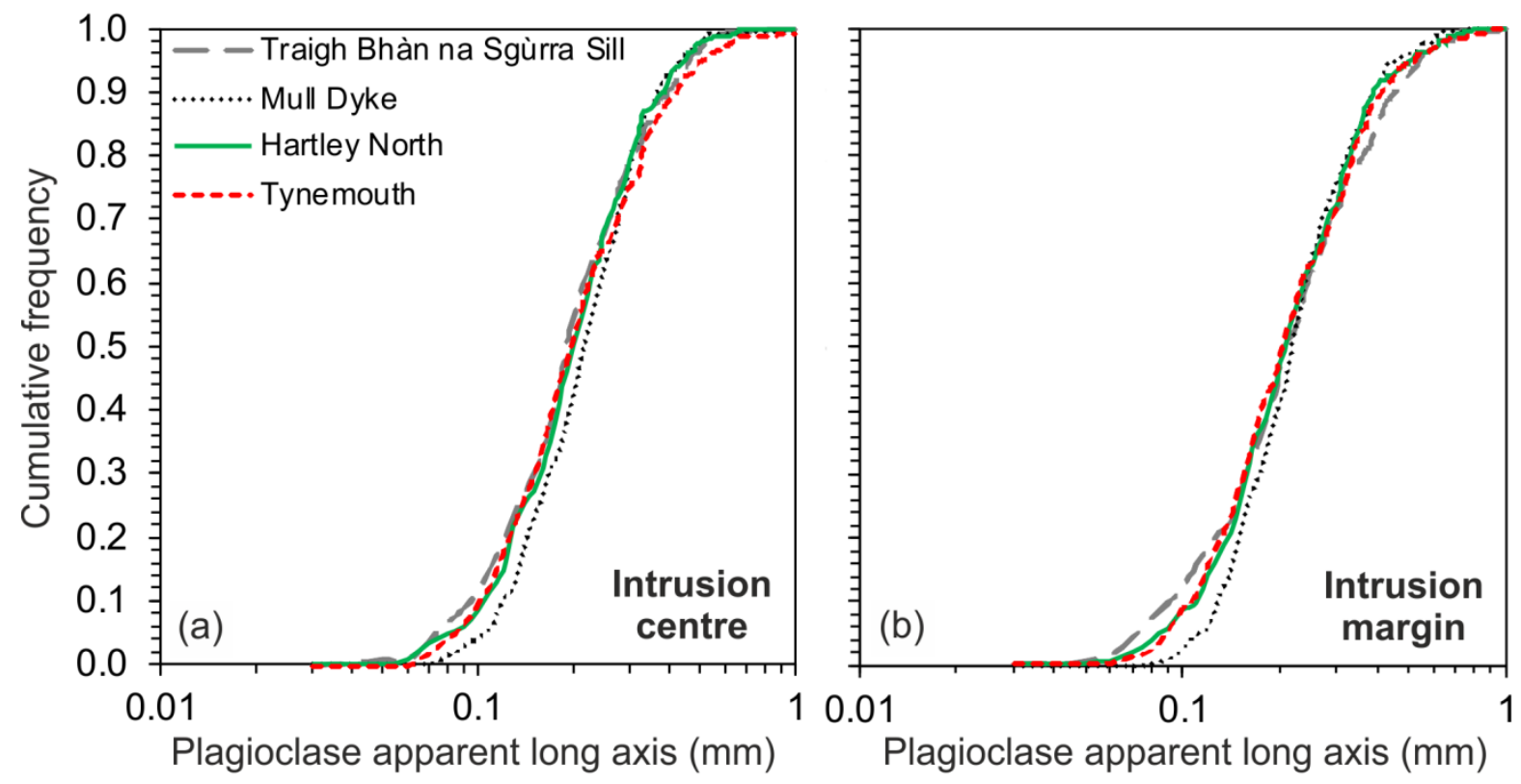

FIG. 7. The cumulative frequency distributions of grain sizes (measured as the length of the apparent long axis of plagioclase as viewed in thin section) in the centres (a) and margins (b) of the Tynemouth and Hartley North Dykes. A typical convecting dyke (a $3.7 \mathrm{~m}$ wide basaltic dyke on the coast of the Isle of Mull) and a non-convecting sill (the $3.5 \mathrm{~m}$ wide Traigh Bhan na Sgurra basaltic sill on the Isle of Mull) with similar average grain sizes to the Northeast England Dykes are shown for comparison (data from Holness et al. (2017)). Static systems have a greater range of grain sizes than convecting systems; the Tynemouth and Hartley North Dykes correspond more closely with the static example).

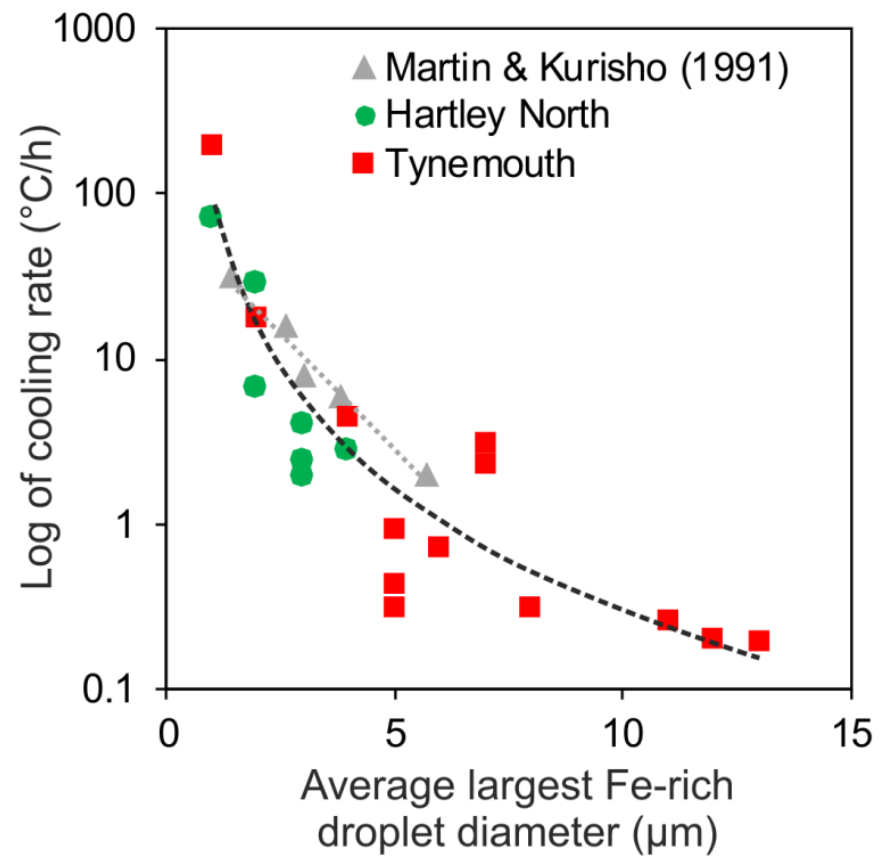

FIG. 8. The relationship between Fe-rich droplet size (average of 5 largest droplets per sample) and the cooling rate (Table 3) for the Hartley North and Tynemouth Dykes. Data from Martin and Kushiro (1991) are shown for comparison. The grey dots are for data from Martin and Kushiro (1991) with a trendline showing an exponential regression, while the black dashes are for the whole data set with a trendline showing a power law regression. 


\section{REFERENCES}

Ágústsdóttir, T., Woods, J., Greenfield, T., Green, R.G., White, R.S., Winder, T., Brandsdóttir, B., Steinthórsson, S. and Soosalu, H. (2016) Strike-slip faulting during the 2014 BárðarbungaHoluhraun dike intrusion, central Iceland. Geophysical Research Letters, 43, 1495-1503.

Applegarth, L.J., Tuffen, H., James, M.R., Pinkerton, H. and Cashman, K.V. (2013) Direct observations of degassing-induced crystallization in basalts. Geology, 41, 243-246.

Ayele, A., Keir, D., Ebinger, C., Wright, T.J., Stuart, G.W., Buck, W.R., Jacques, E., Ogubazghi, G. and Sholan, J. (2009) September 2005 mega-dike emplacement in the Manda-Harraro nascent oceanic rift (Afar depression). Geophysical Research Letters, 36, L20306.

Cashman, K.V. (1993) Relationship between plagioclase crystallization and cooling rate in basaltic melts. Contributions to Mineralogy and Petrology, 113, 126-142.

Cawthorn, R.G. and Walraven, F. (1998) Emplacement and Crystallization Time for the Bushveld Complex. Journal of Petrology, 39, 1669-1687.

Chambers, L.M. and Pringle, M.S. (2001) Age and duration of activity at the Isle of Mull Tertiary igneous centre, Scotland, and confirmation of the existence of subchrons during Anomaly 26r. Earth and Planetary Science Letters, 193, 333-345.

Charlier, B. and Grove, T.L. (2012) Experiments on liquid immiscibility along tholeiitic liquid lines of descent. Contributions to Mineralogy and Petrology, 164, 27-44.

Farr, R.S., Honour, V.C. and Holness, M.B. (2017) Mean grain diameters from thin sections: matching the average to the problem. Mineralogical Magazine, 81, 515-530.

Fischer, L.A., Wang, M., Charlier, B., Namur, O., Roberts, R.J., Veksler, I.V., Cawthorn, R.G. and Holtz, F. (2016) Immiscible iron- and silica-rich liquids in the Upper Zone of the Bushveld Complex. Earth and Planetary Science Letters, 443, 108-117.

Frietsch, R. (1978) On the magmatic origin of iron ores of the Kiruna type. Economic Geology, 73, 478-485.

Giordano, D., Nichols, A.R. and Dingwell, D.B. (2005) Glass transition temperatures of natural hydrous melts: a relationship with shear viscosity and implications for the welding process. Journal of Volcanology and Geothermal Research, 142, 105-118.

Harker, A. and Clough, C.T. (1904) The Tertiary igneous rocks of Skye. J. Hedderwick \& Sons, Glasgow.

Hartlieb, P., Toifl, M., Kuchar, F., Meisels, R. and Antretter, T. (2016) Thermo-physical properties of selected hard rocks and their relation to microwave-assisted comminution. Minerals Engineering, 91, 34-41.

Helz, R.T., Clague, D.A., Sisson, T.W. and Thornber, C.R. (2014) Petrologic Insights into Basaltic Volcanism at Historically Active Hawaiian Volcanoes. Pp. 237-292 in: Characteristics of Hawaiian Volcanoes (M.P. Poland, T.J. Takahashi, and C.M. Landowski, editors), USGS Professional Paper 1801.

Heslop, M. and Smythe, J. (1910) On the Dyke at Crookdene (Northumberland) and its Relations to the Collywell, Tynemouth, and Morpeth Dykes. Quarterly Journal of the Geological Society, 66, 1-18.

Holmes, A. and Harwood, H. (1929) The tholeiite dikes of the north of England. Mineralogical Magazine, 22, 1-52.

Holness, M.B. (2014) The effect of crystallization time on plagioclase grain shape in dolerites. Contributions to Mineralogy and Petrology, 168, 1076.

Holness, M.B., Neufeld, J.A., Gilbert, A.J. and Macdonald, R. (2017) Orientation of Tabular Mafic Intrusions Controls Convective Vigour and Crystallization Style. Journal of Petrology, 58, 2035-2053.

Holness, M.B., Richardson, C. and Helz, R.T. (2012) Disequilibrium dihedral angles in dolerite sills: A new proxy for cooling rate. Geology, 40, 795-798.

Holness, M.B. and Sawyer, E.W. (2008) On the pseudomorphing of melt-filled pores during the crystallization of migmatites. Journal of Petrology, 49, 1343-1363. 
Holness, M.B., Stripp, G., Humphreys, M., Veksler, I.V., Nielsen, T.F. and Tegner, C. (2011) Silicate liquid immiscibility within the crystal mush: late-stage magmatic microstructures in the Skaergaard intrusion, East Greenland. Journal of Petrology, 52, 175-222.

Honour, V. C., M. B. Holness, B. Charlier, S. C. Piazolo, O. Namur, T. J. Prosa, I. Martin, R. T. Helz, J. Maclennan, M. M. Jean (2019a). Compositional Boundary Layers Trigger Liquid Unmixing in a Basaltic Crystal Mush. Nature Communications, 10, 4821.

Honour, V.C., Holness, M.B., Partridge, J.L. and Charlier, B. (2019b) Microstructural evolution of silicate immiscible liquids in ferrobasalts. Contributions to Mineralogy and Petrology, 174, 77.

Hort, M. (1998) Abrupt change in magma liquidus temperature because of volatile loss or magma mixing: effects on nucleation, crystal growth and thermal history of the magma. Journal of Petrology, 39, 1063-1076.

Humphreys, M.C. (2011) Silicate liquid immiscibility within the crystal mush: evidence from Ti in plagioclase from the Skaergaard intrusion. Journal of Petrology, 52, 147-174.

Jakobsen, J.K., Veksler, I.V., Tegner, C. and Brooks, C.K. (2011) Crystallization of the Skaergaard intrusion from an emulsion of immiscible iron-and silica-rich liquids: evidence from melt inclusions in plagioclase. Journal of Petrology, 52, 345-373.

James, G., Witten, D., Hastie, T. and Tibshirani, R. (2013) An introduction to statistical learning. Springer, New York.

Jolly, R.J.H. and Sanderson, D.J. (1995) Variation in the form and distribution of dykes in the Mull swarm, Scotland. Journal of Structural Geology, 17, 1543-1557.

Jones, J.M. (1967) The Geology of the coast section from Tynemouth to Seaton Sluice. Transactions of the Natural History Society of Northumbria, 16, 153-192.

Kerr, A.C., Kent, R.W., Thomson, B.A., Seedhouse, J.K. and Donaldson, C.H. (1999) Geochemical Evolution of the Tertiary Mull Volcano, Western Scotland. Journal of Petrology, 40, 873-908.

Kirkpatrick, R.J. (1977) Nucleation and growth of plagioclase, Makaopuhi and Alae lava lakes, Kilauea Volcano, Hawaii. Geological Society of America Bulletin, 88, 78-84.

Kohn, S. (2000) The dissolution mechanisms of water in silicate melts; a synthesis of recent data. Mineralogical Magazine, 64, 389-408.

Land, D.H. (1974) Geology of the Tynemouth district. HM Stationery Office, London.

Lester, G., Clark, A., Kyser, T. and Naslund, H. (2013) Experiments on liquid immiscibility in silicate melts with $\mathrm{H} 2 \mathrm{O}, \mathrm{P}, \mathrm{S}, \mathrm{F}$ and $\mathrm{Cl}$ : implications for natural magmas. Contributions to Mineralogy and Petrology, 166, 329-349.

Levich, V.G. (1962) Motion and diffusion in thin liquid films. Pp. 689-700 in: Physicochemical hydrodynamics (N.R. Amundson, editors), Prentice-Hall, Englewood Cliffs.

Macdonald, R., Baginski, B., Upton, B., Pinkerton, H., Maclnnes, D. and MacGillivray, J. (2010) The Mull Palaeogene dyke swarm: Insights into the evolution of the Mull igneous centre and dyke-emplacement mechanisms. Mineralogical Magazine, 74, 601-622.

Martin, B. and Kushiro, I. (1991) Immiscibility synthesis as an indication of cooling rates of basalts. Journal of Volcanology and Geothermal Research, 45, 289-310.

Martin, D., Griffiths, R.W. and Campbell, I.H. (1987) Compositional and thermal convection in magma chambers. Contributions to Mineralogy and Petrology, 96, 465-475.

McNaught, A.D. (1997) Compendium of chemical terminology. Blackwell Science, Oxford.

Mitchell, J.G., Rands, P.N. and Ineson, P.R. (1989) Perturbation of the K-Ar age system in the Cleveland dyke, UK: evidence of an Early Eocene age for barite mineralisation in the Magnesian Limestone of County Durham. Chemical geology, 79, 49-64.

Ostwald, W. (1897) Studien über die Bildung und Umwandlung fester Körper. Zeitschrift für Physikalische Chemie, 22, 289-330.

Peltier, A., Ferrazzini, V., Staudacher, T. and Bachèlery, P. (2005) Imaging the dynamics of dyke propagation prior to the 2000-2003 flank eruptions at Piton de La Fournaise, Reunion Island. Geophysical Research Letters, 32, L22302. 
Philpotts, A. (1982) Compositions of immiscible liquids in volcanic rocks. Contributions to Mineralogy and Petrology, 80, 201-218.

Philpotts, A.R. (1978) Textural evidence for liquid immiscibility in tholeiites. Mineral Magazine, 42, 417-425.

Philpotts, A.R. (1979) Silicate liquid immiscibility in tholeiitic basalts. Journal of Petrology, 20, 99-118.

Philpotts, A.R. (1981) A model for the generation of massif-type anorthosites. The Canadian Mineralogist, 19, 233-253.

Pupier, E., Duchene, S. and Toplis, M.J. (2008) Experimental quantification of plagioclase crystal size distribution during cooling of a basaltic liquid. Contributions to Mineralogy and Petrology, 155, 555-570.

Putnis, A. and Mauthe, G. (2001) The effect of pore size on cementation in porous rocks. Geofluids, 1, 37-41.

Roedder, E. (1951) Low Temperature liquid immiscibility in the system K2O-FeO-Al2O3-SiO2. American Mineralogist, 36, 282-286.

Ryan, M.P. and Sammis, C.G. (1981) The glass transition in basalt. Journal of Geophysical Research: Solid Earth, 86, 9519-9535.

Saunders, A., Fitton, J., Kerr, A., Norry, M. and Kent, R. (1997) The north Atlantic igneous province. Large igneous provinces: Continental, oceanic, and planetary flood volcanism, 100, 45-93.

Schiavi, F., Walte, N. and Keppler, H. (2009) First in situ observation of crystallization processes in a basaltic-andesitic melt with the moissanite cell. Geology, 37, 963-966.

Sloan, T. (1971) The structure of the Mull tertiary dyke swarm. Ph.D. thesis, University of London.

Teall, J. (1889) On the Amygdaloids of the Tynemouth Dyke. Geological Magazine, 6, 481-483.

Teall, J.J.H. (1884) Petrological notes on some North-of-England dykes. Quarterly Journal of the Geological Society, 40, 209-247.

Underhill, J.R. (2009) Role of intrusion-induced salt mobility in controlling the formation of the enigmatic 'Silverpit Crater', UK Southern North Sea. Petroleum Geoscience, 15, 197-216.

Veksler, I.V., Dorfman, A.M., Borisov, A.A., Wirth, R. and Dingwell, D.B. (2007) Liquid immiscibility and the evolution of basaltic magma. Journal of Petrology, 48, 2187-2210.

Veksler, I.V., Dorfman, A.M., Danyushevsky, L.V., Jakobsen, J.K. and Dingwell, D.B. (2006) Immiscible silicate liquid partition coefficients: implications for crystal-melt element partitioning and basalt petrogenesis. Contributions to Mineralogy and Petrology, 152, 685-702.

Veksler, I.V., Dorfman, A.M., Rhede, D., Wirth, R., Borisov, A.A. and Dingwell, D.B. (2008) Liquid unmixing kinetics and the extent of immiscibility in the system $\mathrm{K} 2 \mathrm{O}-\mathrm{CaO}-\mathrm{FeO}-\mathrm{Al} 2 \mathrm{O} 3-\mathrm{SiO} 2$. Chemical geology, 256, 119-130.

Wall, M., Cartwright, J., Davies, R. and McGrandle, A. (2010) 3D seismic imaging of a Tertiary Dyke Swarm in the Southern North Sea, UK. Basin Research, 22, 181-194.

Wright, T.J., Ebinger, C., Biggs, J., Ayele, A., Yirgu, G., Keir, D. and Stork, A. (2006) Magma-maintained rift segmentation at continental rupture in the 2005 Afar dyking episode. Nature, 442, 291.

Yao, W., Maris, H., Pennington, P. and Seidel, G. (2005) Coalescence of viscous liquid drops. Physical Review E, 71, 016309.

Yoder, H., Stewart, D. and Smith, J. (1957) Feldspars. Carnegie Institution Washington Yearbook, 56, 206-214.

Zellmer, G.F., Sakamoto, N., Hwang, S.-L., Matsuda, N., lizuka, Y., Moebis, A. and Yurimoto, H. (2016) Inferring the Effects of Compositional Boundary Layers on Crystal Nucleation, Growth Textures, and Mineral Chemistry in Natural Volcanic Tephras through Submicron-Resolution Imaging. Frontiers in Earth Science, 4, 88. 